\title{
Management tools for the sustainable reclaiming of historical neighbourhoods
}

\author{
Nicola Costantino*
}

\begin{abstract}
The sustainable reclaiming of historical neighbourhoods can be achieved only by projects able to allow to all the public and private involved subjects to receive benefits (not necessarily only the economic ones) larger than the related (financial, but also social and cultural) costs. In the case (really very common) of significantly deteriorate urban areas, such projects can be developed if it's possible to overcome a minimum "critical" dimension, in order to register a real estate enhancement that offers values of the restored buildings greater than the project's cost. The paper presents two management tools instrumental in reaching the critical dimension and in guarantying an adequate project quality: Public Private Partnership, via Project financing, can be an effective instrument to collect private financial resources for the reclaiming of public owned buildings; while the Neighbourhood laboratory is a strategic tool to support the single private owners (often families with only a flat in an apartment building) to reclaim their estate respecting all the necessary architectural and technical obligations.
\end{abstract}

Keywords: Sustainable reclaiming, Historical neighbourhoods, Public Private Partnership, Project financing, Laboratorio di Quartiere, Neighbourhood laboratory

\section{The sustainable reclaiming}

A seminal definition for sustainable development was proposed by the Brundtland Commission in 1987: "Development that meets the needs of the present without compromising the ability of future generations to meet their own needs" (World Commission on Environment and Development's 1987).

Urban renewal and rehabilitation generally comply with this principle, as they use "renewable resources", more properly existing resources such as buildings and urban space, making their functioning more sustainable, by enhancing energy saving or using environmentally safe materials, and preventing the use of other non-renewable resources, such as non-urbanized areas. We can consider, according with the CIB (1999) statements, that a reclaiming project of an inner-city neighbourhood can be considered sustainable if:

*Correspondence: nicola.costantino@poliba.it Politecnico di Bari, Dipartimento di Meccanica, Matematica e Management, Viale Japigia 182, 70126 Bari, Italy
- It avoids the substitution of the old buildings with new ones, minimizing the waste and improving the long-term (indeed, in some case, a very, very long term) performance of the buildings, instead of the short time horizons involved in usual "new" projects (Bon 1999).

- It is respectful of the cultural, functional, technological, and social history of the neighbourhood, allowing, as well as it is possible, and at least in part, the ancient inhabitants and owners to keep their houses while (and after) upgrading them.

- It can be entirely financed by local real estate market, without too expensive public projects (that is to say, it is financially sustainable too).

A definition of successful reclaiming projects is not easy to find. Real estate literature generally defines and measures a project's success through strictly economic indicators, from the developers'-investors' point of view. Social sciences, on the other hand, along with socio-economic development and planning, look at different outcomes, all related to the quality of life in the area before and after the project. Evaluation has been 
broadly discussed in literature, with a recent shift in studies towards impact assessment. Not merely a change in terminology, this new approach tends to have a greater focus on the outcomes of the interventions, rather than inputs and outputs (Hulme 2000); and to evaluate such outcomes during the full life of the project, through the Life Cycle Assessment (LCA) tool, that constitutes a very important conceptual improvement also if not always easily applicable in quantitative ways (Ortiz et al. 2009).

So, in the present context, we can intend a project to be successful primarily as referred to the "intended beneficiary", rather than the institutional outreach and institutional sustainability, although these shall not be forgotten.

By a broader point of view, the financial success, that is to say full cost recovery, is subordinated to the involvement and full participation of a sufficient number of stakeholders, as the main aim is not just renewal in order to sell or rent the property. It has an overall added value, as it includes the upgrade of the actual resident's living conditions through the upgrade and maintenance of the existing housing stock and urban infrastructures (thus making urban life more sustainable by not further urbanizing the territory), real-estate market revitalization, complex conflict solving and, sometime, social and ethnic reintegration of refugees and returnees.

A review and comparison of projects in different countries, (Altermann et al. 1991), must look at at least four dimensions: contextual variables, program characteristics, implementation characteristics, and outputs and outcomes. Taking for granted that each programme is unique, the contextual variables are probably the greatest obstacle in comparison and consequent transfer of experience. They include political and ideological structure, demographics and demand for housing, the neighbourhood's original initiator and the role of planning laws and controls. The literature on urban rehabilitation, extremely vast, is primarily based on USA and UK experiences, later extended to the rest of the developed world.

In most of the literature, however, rehabilitation of residential areas is part of large projects of broader urban renewal, with massive public funding. Micro-finance issues as well are more frequently discussed in small enterprise and economic development projects, rather than in urban planning or urban revitalization programs. Only recently joint public-private funded projects in rehabilitation and property development are being explored. Once again reference is mainly made to the UK experience in the 90s, with programmes such as City Challenge or the Single Regeneration Budget (SRB), that have positively supported more effective coordination and integration among different bodies and strategies, while inter-relating economic, social and environmental aspects of urban decline and subsequent rehabilitation (Parkinson 1997).

By a more contingent, and actual, point of view, a successful renovation project should find a reasonable trade-off between "the desire" to maximize the request of poorer and older inhabitants, together with the best conservation of the cultural and historical heritage, and "the need" of a larger recourse to private financial resources in front of always reducing public funding.

\section{The building reappraisal market}

All over Europe, the real estate market in the historical inner-cities' residential areas can in some ways be compared to a transition market, in which it becomes increasingly important. As a matter of fact, the five objectives stated by the European Commission (2013) in its" Construction 2020 Action Plan" are:

1. Stimulating investment conditions for renovation.

2. Improving human capital.

3. Improving resource efficiency.

4. Strengthening the internal market for construction.

5. Fostering the global competitive position of European construction enterprises.

In this context, the share of renovation in the total market is particularly important. The analysis of the construction sector in Italy, for example, shows that $(2015$ data) only $31.4 \%$ of housing investment is represented by new constructions. The remaining $68.6 \%$ of investment consists of activities aimed at the reappraisal and renovation of existent residential buildings (without consider the ordinary maintenance) (ANCI 2015).

At the root of the simple quantitative data, there exist complex factors of diverse natures, such as the flat demographic trend, the aging of the Italian building stock, the prevailing requirement to conform to European regulations in plant-engineering sectors, and the ever increasing interest in the real-estate market for older, existent property. This last, but very important factor is, in turn, the result of very different causes, as is the establishment of new cultural models and the scarcity of new high quality building land. The first aspect could otherwise be defined as a widespread growing desire to conserve and improve the building heritage stock to the highest standard possible, rather than to "replace" it. The second aspect regards the strong line taken by public authorities on the preservation of the remaining unbuilt areas in both the historical centres and semi-central districts as well as in suburbs (Piano et al. 1980).

Considering the overall structure of the real estate, we note that, very often, the historical inner cities' residential areas are characterized by: 
- The sharing of public and private property, with the public quota usually quantitatively small, even if often characterized by very important single buildings.

- A very small to medium size of single (private) properties within the whole neighbourhood.

- A not fully defined real-estate value and vital market.

In such a situation, the degrading phenomena can be very strong, once that they start: a few owners (of the smaller, more deteriorated and less valued apartments) leave them empty and without maintenance; the near remaining apartments suffer the propinquity with such an abandonment context, and become in turn less valuable: consequently, they are rented (or sold), to poorer families and obtain less cures, and so on, with a feedback (snowball effect) that can be very strong. The same feedback phenomena in the reverse trend is, unfortunately, unlikely. Indeed, as we know, the cost of upgrading projects can be considered approximately proportional to the single project dimension, in a wide range of building dimensions. On the other side, the profits of the upgrading projects (the real-estate value of the restored buildings) vary with both the dimension of the single project and the broader extent of the whole upgraded neighbourhood (the "propinquity effect" works both in the degrading and in the upgrading phenomena).

So the market price of a restored apartment (or building, or group of buildings) is:

$$
P=p \times s
$$

where $p$ is the unit price (price for square meter), and $s$ is the surface of the apartment (or building, or group of buildings) involved in the upgrading project. According to the propinquity effect, $p$ depends not only on the quality of the single restored real estate, bur also on the quality (and value) of the whole neighbourhood where the apartment (or the building) is located. So if the upgrading project is bigger (and a whole neighbourhood, with a lot of adjacent buildings is involved), $p$ grows: we can assume (as a first approximation) that is

$$
p=k \times s^{y}
$$

where $y>0$ (indeed, in some local survey in once very degraded areas, we found that it can be $1<\mathrm{y}<2$ or also $3)$. So, for the whole restoration project:

$$
P=k \times s^{(1+y)}
$$

Thus the single project revenue varies (very approximately) in a more than proportional way with the surface (dimension) of the general upgrading project (Fig. 1). Obviously, the propinquity effects work also when there is not a unique restoration project, but more independent

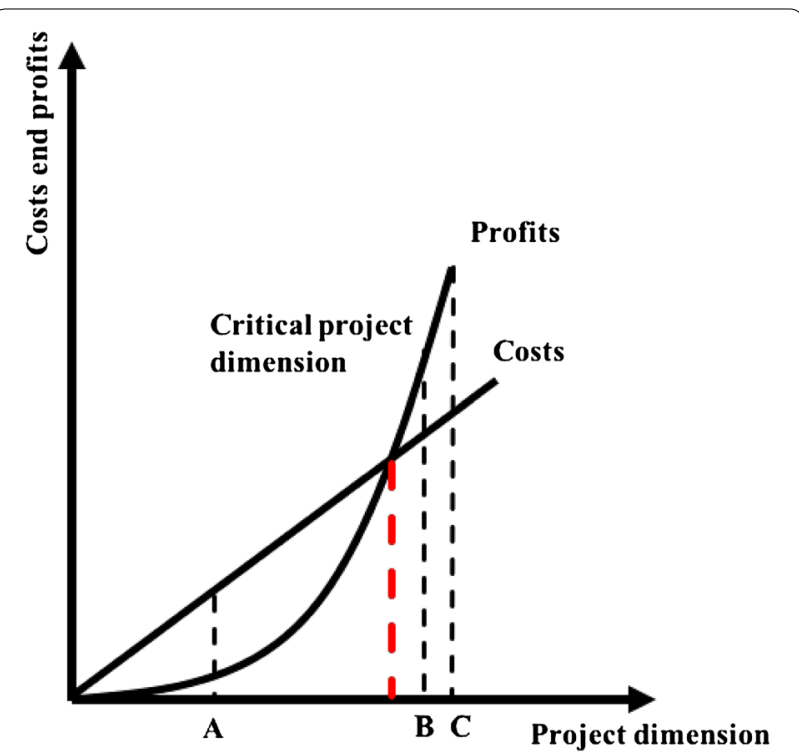

Fig. 1 Critical economic project dimension

projects achieved in the same neighboured by different owner and/or developer.

As we can see, there is a minimal economic dimension of the upgrading project that, in very degraded context, can be relatively high (because the initial real-estate value is very low). Where the medium size of the single (private) properties within the whole neighbourhood is smaller (as in Italian historical inner cities), it can be very difficult that a single owner or developer achieves a project size sufficient to overcome the minimal economic dimension (Costantino 2002).

So, to overcame this dimension and, together, to assure a "correct" (by a cultural, technological, social and economic point of view) development of the process it is necessary:

(a) To promote the renovation of some important (for dimension and/or historical value) building or "cluster" of buildings.

(b) To support the single owners of the small, fragmented properties in the implementation of their individual projects.

When, as often happens, the deterioration of the neighbourhood and the fragmentation of the properties are so high to discourage purely private initiative, the upgrading process needs to be facilitated and supported by the Public Administration, not necessary via direct public funding. To achieve the a) objective (to promote the renovation of some important building or "cluster" of buildings) the Public Private Partnership can be a very useful tool, while to pursue the b) one 
(to support the single owners of the small, fragmented properties in the implementation of their individual projects) it's possible to implement the Neighbourhood laboratory. Both tools require the oversight by the local Public Administrations, but not their direct financial involvement.

\section{The public private partnership}

Often in the historical neighbourhoods there are ancient, important building (as castles, aristocratic palaces, cloisters, military barracks, and so on), owned by the municipality, or by the state, no more used, and gravely deteriorate. The restoration of those edifices usually meets two serious obstacles:

(1) To find new ways to utilize them compatible with their architectural and historical value.

(2) To finance the restoration.

Let's examine the second one: as we know, the real-estate market creation and development can generally be outlined through three main stages (D'Amato 2008) (Fig. 2).

In the first stage, where the overall economy is weak and the financial structures are weak, land owners let their assets to the contractors obtaining "brick", that is to say new buildings, in return. This, extremely simplified, is what happened in the real estate market in the 50s in Italy.

The second stage, achieved by more advanced economies, is the most commonly perceived idea of real estate market, where "solid" assets are sold for currency.

The third stage, where buildings are mainly considered as financial assets in more complex transactions, requires a highly advanced and structured economy.

An important managerial tool to cope with this third stage in the case of public historical real-estate is to find ways to finance the restoration by Public Private Partnership (PPP).

According to the Public-Private Partnerships Reference Guide, a Public Private Partnership is a "long-term contract between a private party and a government entity, for providing a public asset or service, in which the private party bears significant risk and management responsibility, and remuneration is linked to performance" (World Bank 2014). The way in which the private party collect the financial resources and guarantees is known as Project Finance. It is to say "the financing of long-term infrastructure, industrial projects and public services based upon a non-recourse or limited recourse financial structure, in which project debt and equity used to finance the project are paid back from the cash flow generated by the project. Project financing is a loan structure that relies primarily on the project's cash flow for repayment, with the project's assets, rights and interests held as secondary security or collateral. Project finance is especially attractive to the private sector because companies can fund major projects off balance sheet". (www.investopedia.com/terms/p/projectfinance.asp , 2016).

When the municipality, or any other public authority, owns one or more buildings in an historical neighbourhood that could be restored and destined to uses that can generate "entrepreneurial" revenues (for example: libraries, theatres, kindergartens, fitness centres, co-working hubs, but also hotels, $\mathrm{B} \& \mathrm{~B}$, and so on), they can be granted to private entrepreneurs for a limited (but long) time (usually from 20 to 90 or more years).

The entrepreneurs who receives such "concession" establish a new limited-liability company, called "Special Purpose Vehicle" (SPV) because its aim is only to manage the reclaiming and the public use of the granted realestate. The SPV:

- Collects the necessary capital to provide to the restoration of the buildings, usually issuing equities and bonds.

- Operates as General Contractor for the reclaiming project, according with a design approved by the public owner.

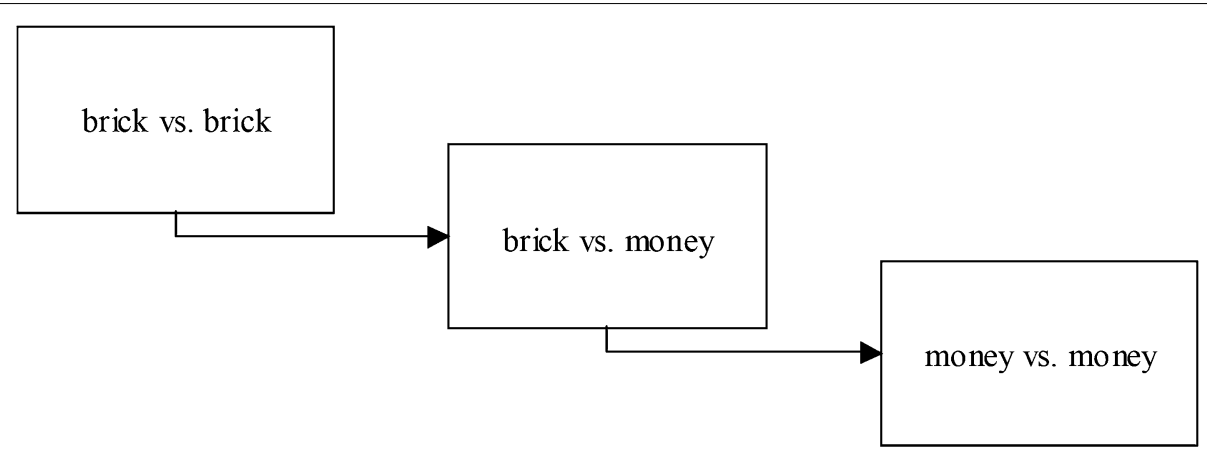

Fig. 2 Real estate market development stages 
- Runs the restored buildings in their new destination, using the collected revenues to remunerate the equities and the bonds.

- At the end of the granted time, returns the real-estate to the public owner, that can grant it again (to the same SPV or to another one); otherwise it can decide to use it directly (or to sell it). It's important that the granted time (concession period) is calculated in order to give a fair (but not exorbitant) economic and financial return to the private partner (Pellegrino et al. 2014).

Operating in such a way, a municipality (or other public owner), can obtain to promote (with private capitals) enough rehabilitation projects in a deteriorated historical neighbourhood to meet, and overcome, the critical dimension over described.

So it became possible (because advantageous) for the private owners of the other single buildings (or, more often, family flats in apartment buildings) in the same neighbourhood to start individual reclaiming projects.

\section{The neighbourhood laboratory experience}

In such a situation, the financial sustainability problem can be considered solved (due to the overcoming of the critical dimension threshold through private capitals invested in the PPP projects), but a "quality" question endures, because in single small (often, very small) rehabilitation projects, directly managed by the private owners, there are no guaranties about the technological and cultural quality of the design and the fulfilment, that inevitably affect the whole architectural and urban quality of the restored neighbourhood.

An interesting and useful management tool to overcame those important problems is the Neighbourhood laboratory ("Laboratorio di Quartiere"), successfully experienced in Italy since 1979.

In effect, there is a fundamental contradiction between the small (often very small) physical and financial dimension of the single private rehabilitation project, and its technical (and sometime historical and architectural) complexity. The growing demand in quality urban recovery work in the (many, different and close) projects prompts for-in the first instance-technological innovation of process: new support services and multifunctional activities such as technical diagnostic and construction monitoring services, training (also directed at the final consumer), management of local knowledge, identification of those private and public resources available for urban reappraisal, experimentation with soft technology to improve the lifestyles of the various categories of urban consumer.

New or "renewed" organizational techniques, based on the management and on the analysis of knowledge and information flow are needed. Those knowledge and information prove to be extremely vast and complex in the sphere of urban recovery, especially when the active involvement of several different participants, such as private companies, the Public Administration, and the citizens, is taken into consideration. Moreover, the growing instances for a more sustainable approach to urban management encourages also a reuse of existing inner cities that involves huge neighbourhoods in a "soft" way, i.e. in a way that is respectful of the social and cultural needs of the involved inhabitants.

In such a dynamic context, the Neighbourhood laboratory (NL-"Laboratorio di Quartiere")—of which Gianfranco Dioguardi, along with Renzo Piano, has been the designer and main experimentalist in the span of about 30 years-can represent a sort of decentralized "virtual structure" in which to strategically manage information and multidisciplinary skills, adapting them in an optimum way and targeting the offer of the new qualitative and quantitative levels of local demand (Piano et al. 1980; Amendola et al. 1995).

In the more recent configuration, it takes the form of a component in a highly complex network project, supported by telecommunication linkups and organizational interconnections in conformity with the local authority planning policies on reappraisal, development, conservation, and fulfilment of the finished product. When such a network is integrated with local organization, it can lead to a "municipal centre" in which to carry out the activities of coordination, participation, and control of decentralized activities in the outskirts and the various urban contexts.

Logistically the Laboratory must be supported by buildings (preferably public buildings) suitable for the fulfilment of its cultural and formative activities, a citizens' information and help desk, as well as by advanced technological equipment and services. In particular, there is a need for information and telecommunications systems in order to gather, elaborate and update the databanks and hypertexts, and for the related communications system.

The first Laboratory, experimented in Otranto in 1979, identified four basic sections: analysis and diagnosis, open project, work and construction, and documentation and information.

A general directory of the main activities to be carried out by the professionals, contractors and institutions interested in the Laboratory is: 
1. Technical services

- Design, diagnosis and technology support to small, "spontaneous" reclaiming projects carried on by single owners of little buildings, or parts of buildings. This support is carried on together with medium and large engineering and construction firms, and is oriented to allow the inhabitants, every time it is possible, to remain in their houses during the project.

- Maintenance and management of the public properties (outlining, mapping, gathering and elaboration of maintenance and management data about road links, installation networks, cultural assets and the public heritage "in use" or, if out of use, available for rehabilitation and re-use).

- Maintenance and management of privately owned historical buildings which, with advanced services, could be offered on the market (possibly by Public Private Partnership).

2. Public services

- Coordinating of single, individual reclaiming projects in more complex, complete and sustainable neighbourhood projects.

- Socio-demographic analysis of residents, using personal and demographic data obtained from the public database that are capable of carrying out both ordinary administrative activities and cognitive analysis of the present and future "demand" for services on the part of the inhabitants.

- Information/telecommunication support for sport, social and cultural activities.

- Liaison with local schools to realize the training programs on the ground, in relation to urban sustainability, ecological activities, the best utilization of the local historical and cultural heritage.

- Services for environmental sustainability, conservation of natural areas and public spaces, water treat- ment and reclamation of polluted areas, and local waste recycling.

- Study and proposals for renewable energetic sources and energy-saving devices (related to local peculiarity).

- Security services for residential and commercial premises and surveillance of municipal spaces.

For other activities, such as voluntary and social assistance services, the Laboratory is able to act as local agent for the development in demand (information on socially useful services and related promotional marketing) and, at the same time, for qualitative and quantitative improvement in supply.

So, in some ways, the laboratory brings consistency to the actions of both the public and private parties, with the intention of saving resources by the conservation and capitalization of the cultural assets at its disposal. They can be offered new stimuli and suitable responses, to which the Public Administration must guarantee congruity with the general objectives, while the system of contractors can ensure compatibility with the financial limitation and the need for quality.

The unceasing experimental evolution of the Neighbourhood Laboratories can be found in a large bibliography. The Neighbourhood laboratory has been experimented several times in the last 30 years in Italy (the most important experiences are described in Table 1). In those experiences the technical, social and cultural results were generally satisfactory for the involved subjects: city authorities, citizens, craftsmen, professionals, general contractors (Dioguardi 2015). As shown by the table, the single experiences were focused on different issues related to the specific, local needs, but all ones shared the "philosophy" of the first experiment in Otranto: offer to the local inhabitants and craftsmen technical, architectural and cultural consultancy for a more aware and sustainable development of their single rehabilitation projects.

Table 1 Neighbourhood laboratory principal experiences in Italy

\begin{tabular}{|c|c|c|}
\hline City & Year & Experience \\
\hline Otranto & 1979 & $\begin{array}{l}\text { Degrade diagnosis, technical consultancy for local craftsmen, inhabitants shared design of public spaces projects in an ancient, } \\
\text { historical neighbourhood }\end{array}$ \\
\hline Bari Japigia & $\begin{array}{l}1980 \\
1985\end{array}$ & $\begin{array}{l}\text { Technical consultancy (particularly for energy saving problems) and writing of a "home directions books" in a recent (about } \\
\text { 20-30 years old), but degraded neighbourhood }\end{array}$ \\
\hline Otranto & 1992 & $\begin{array}{l}\text { Inhabitants shared urban design, business and technical consultancy for new enterprises in the "urban services" field (for the } \\
\text { whole city) }\end{array}$ \\
\hline Rome & 1993 & $\begin{array}{l}\text { Writing of a "neighbourhood hypertext", to help professionals, craftsmen and citizens to develop upgrading projects in the } \\
\text { ancient "Ghetto" neighbourhood }\end{array}$ \\
\hline Cosenza & $\begin{array}{l}1994 \\
1996\end{array}$ & $\begin{array}{l}\text { Writing and experimental use of a "inner city hypertext", to help professionals, local craftsmen and citizens to develop upgrading } \\
\text { projects in the ancient inner city }\end{array}$ \\
\hline
\end{tabular}




\section{Conclusions}

The demand for the sustainable reclaiming of historical neighbourhoods (and, more generally, for deteriorated inner cities) is growing from at least 30 years in all over the developed world. Real-estate free market dynamics often are unable to achieve the operative conditions to develop recovery projects in a culturally, socially and financially sustainable way. On the other way, the huge dimension of the problem is usually not compatible with the direct financial intervention of the state or local Public Administrations. Project Private Partnership and Neighbourhood laboratory can be two useful organizational tools able to give positive responses to such a demand without demanding such an intervention.

\section{Competing interests}

The author declares that he has no competing interests.

Received: 29 October 2016 Accepted: 6 January 2017

Published online: 14 January 2017

\section{References}

Altermann R, Cars G (1991) Neighbourhood regeneration: an international evaluation. Munsell, London

Amendola G, Sivo G (1995) L'Agorà efficiente. Limpresa e la città creativa. Clear, Roma
ANCE Direzione Affari Economici e Centro Studi (2015) Osservatorio Congiunturale Sull'Industria delle Costruzioni, Roma

Bon R (1999) Sustainable construction: some economic challenges, proceedings of sharing knowledge on sustainable building - mediterranean conference, Bari, 16-17/12/1999

CIB (1999) Agenda 21 on sustainable construction http://www.irbnet.de/ daten/iconda/CIB4675.pdf

Costantino N (2002) An economic and organisational approach to the sustainable renewal of historical neighbourhood. Int J Environ Technol Manag 2:291-301

D'Amato M (2008) Informazione e Mercato Immobiliare. In: D'Amato M, Del Giudice V (eds) Principi Metodologici per la Costruzione degli Indici dei Prezzi nel Mercato Immobiliare. Maggioli Editore, Rimini

Dioguardi G (2015) Nuove alleanze per il terzo millennio. Città metropolitane e periferie recuperate. FrancoAngeli, Milano

European commission (2013) Construction 2020 action plan, document COM (2012) 433 final

Hulme D (2000) Impact assessment methodologies for microfinance: theory, experience and better practice. World Dev 28(1):79-98

Ortiz O, Castells F, Sonnemann G (2009) Sustainability in the construction industry: a review of recent developments based on LCA. Constr Build Mater 23:28-39

Parkinson M (1997) Urban policy in Britain. Liverpool John Moores University, Liverpool

Pellegrino R, Carbonara N, Costantino N (2014) Concession period for PPPs: a win-win model for a fair risk sharing. Int J Proj Manag 32(7):1223-1232

Piano R, Arduino M, Fazio M (1980) Antico è bello. II recupero della città. Laterza, Bari

World Bank (2014) Public-Private Partnerships Reference Guide Version 2.0

World Commission on Environment and Development's (1987) Our common future. Oxford University Press, Oxford

www.investopedia.com/terms/p/projectfinance.asp (2016)

\section{Submit your manuscript to a SpringerOpen ${ }^{\circ}$ journal and benefit from:}

- Convenient online submission

- Rigorous peer review

- Immediate publication on acceptance

- Open access: articles freely available online

- High visibility within the field

- Retaining the copyright to your article 